\title{
Risk analysis in the spillway of dam Orós by excess of influent flow
}

\author{
ADBEEL GOES FILHO \\ Departamento Nacional de Obras Contra as Secas - DNOCS \\ Av. Duque de Caxias, 1700, $9^{\circ}$ andar, Centro, 60035-111 Fortaleza, CE, Brasil \\ Manuscript received on June 6, 2011; accepted for publication on May 21, 2012
}

\begin{abstract}
This paper presents the practical application of concepts, and some methods of risk analysis, to check the possibility of overcoming a water level of project in the spillway of dam Orós, by excess of influent flow. Also evaluated the empirical formulas contained in the original design. Due to the difficulty of obtaining design data from the dam, since the end of construction date of January, 11, 1961, we minimize the effects of some variables in the calculations, leading us to the consequent simplification of the scenario under study. For a better evaluation and characterization of the setting, some variables in the model such as water level, accumulation and flow of the spillway, had updated their data to June 28, 2011. We have demonstrated the importance of risk analysis for project design, construction and operation of large reservoirs, and the need for ongoing assessments of works of this nature.
\end{abstract}

Key words: risk analysis, public dams, reservoirs, water resources management.

\section{INTRODUCTION}

The aim of this paper is to show the practical application of risk analysis, according to Vieira (2005), considering the case of public reservoir President Juscelino Kubitschek de Oliveira, popularly known as Orós. The dam is located in the municipality of Orós, Ceará state, northeastern Brazil, barring the river Jaguaribe, in the subbasin of the Upper Jaguaribe, and one of the most important rivers of the state, draining an area of approximately $25,000 \mathrm{~km}^{2}$.

River Jaguaribe has as major tributaries the rivers Jucás, Bastiões, Cariús, the stream of Conceição and others, whose waters flow into the Orós reservoir, one of the largest in the state. To

E-mail: adbeel.goes@gmail.com / adbee1@unifor.br simplify we did not consider the influences of other tributaries in the scenario, that will certainly influence the operations of the dam. Due to the antiquity of the reservoir, we had certain difficulties in the recovery of original design and subsequent data collection, which has led us to minimize the effects of some variables in the calculations and simplification of the scenario. We also updated hydrological data flow affluent, if compared to the original project (year of 1912 to 1934). The project used data flows and the empirical limnimetric formulas according to Aguiar (1978), subsequently checked with the Elman neural networks, as well as some analysis about the empirical formulas used to verify data consistency.

The dam Orós is located in the municipality of Orós, faraway $450 \mathrm{~km}$ from Fortaleza, capital of Ceará state (Figure 1). The basin covers an area of 
$25,500 \mathrm{~km}^{2}$. The project aims to irrigate lands in the watersheds of the Upper and Middle Jaguaribe, as well as fish farming, tourism, hydroelectric power and the perennialization of the river Jaguaribe. Designed and built by National Department of Works Against Drought, with the participation of the consultant Casemiro José Munarski and the Hydrotechnical Laboratory Saturnino de Brito SA.

Since the time of the Brazilian empire, the dam Orós was a source of reflections. Only in the Republican period, in the early years of the Federal Inspectorate for Works Against Drought, established

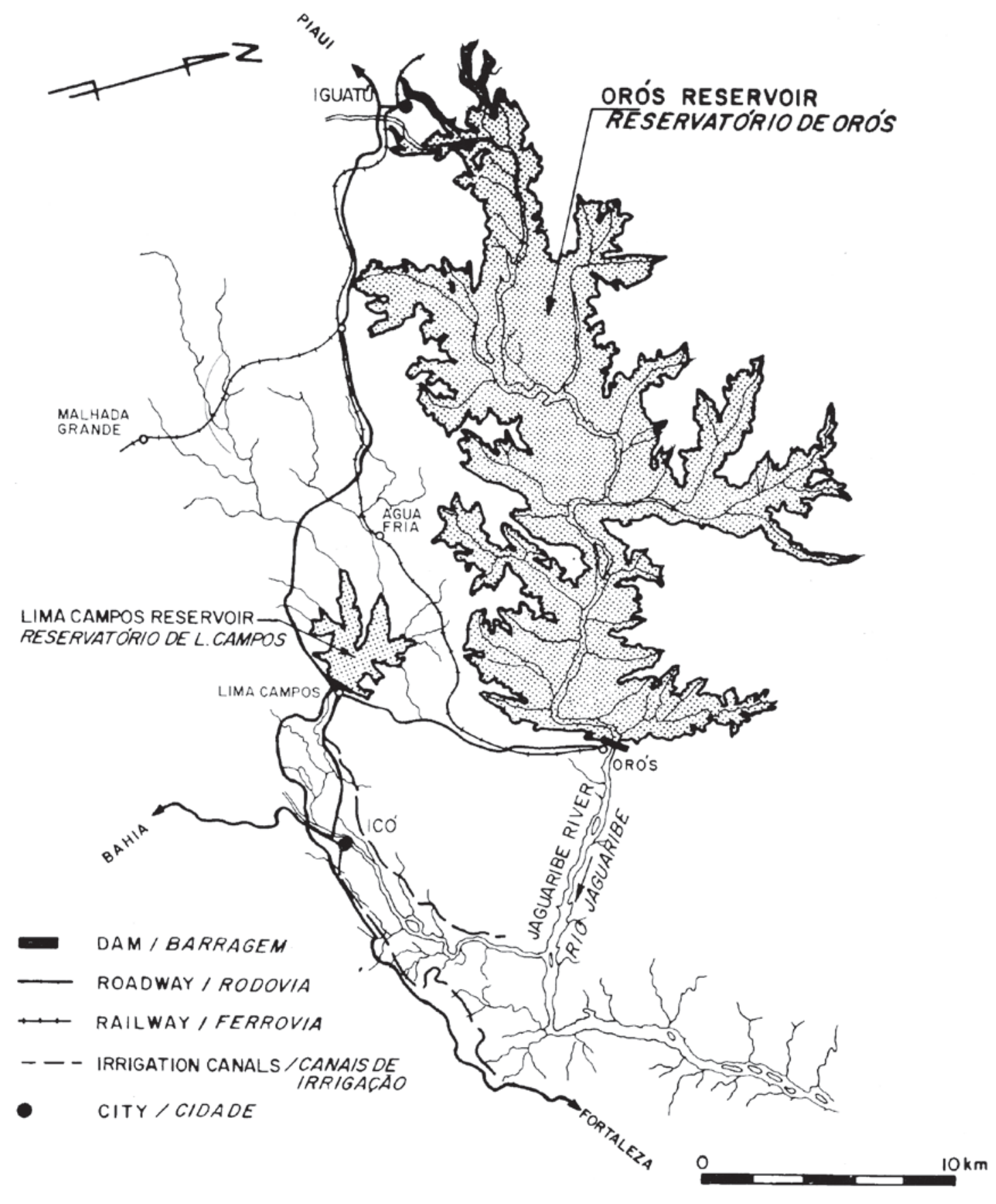

Figure 1 - Orós reservoir (Araújo 1990). 
in 1909, it was studied and completed the draft of the dam, destroyed by fire in 1912. During the drought of 1919, the Federal Government hired a U.S. company, Dwight P. Robinson \& Co. to develop a new project and perform the work, however, technical reasons have prevented its construction. In the year 1924, an extreme flood destroyed parts of the premises that has already begun, following the stoppage of works and services. An extreme drought followed again in 1932, which mobilized the whole team and the contribution of new federal resources. Under the guidance of Luiz Vieira, new projects were designed, one for earth dam, concrete dam to another, both straight shaft located downstream of the abyss, both subsequently discarded.

Around the year of 1957, Arthur W. Schneider made further lithological and structural studies, with polls indicating a strong presence of rock, sand and clay in the vicinity, prompting even the consultant, Casemiro José Munarski, suggesting the final project. Economic reasons and availability of equipment induced by dam Araras, recently completed, led the construction of a dam on zoned land. The beginning of its construction date of 1958, when the foundations were dug. It suffered a series of stoppages, and in January 11, 1961, it was then inaugurated by the President Juscelino Kubitschek de Oliveira (Araújo 1990).

The dam Orós consists of a mass of land zoned, with an impermeable clay core, followed by upstream and downstream sections of sand covered with riprap. It consists of a landfill whose crest is at elevation $209 \mathrm{~m}$, with a crown width of $10 \mathrm{~m}$. The upstream slope is $1 \mathrm{~V}: 2.5 \mathrm{H}$ elevation to 180 $\mathrm{m}$, continuing with $1 \mathrm{~V}: 3 \mathrm{H}$ to the base. It is the downstream slope of $1 \mathrm{~V}$ : $2 \mathrm{H}$ to elevation $180 \mathrm{~m}$, and $1 \mathrm{~V}: 2.5 \mathrm{H}$ to the ground surface.

The spillway, the object under study, designed by the Laboratory Saturnino de Brito, is part of a sill, bent axis and $180 \mathrm{~m}$ wide, divided by 13 pillars spaced about $14 \mathrm{~m}$ axis to axis, with span of 160 $\mathrm{m}$, built to support future floodgates that would increase to 4 billion cubic meters of its maximum accumulation capacity. The channel aspect ends up a ski jump with variable section in Creager profile, and flow control is not performed for lack of gates, in other words, free-flow.

\section{MATERIALS AND METHODS}

The rainfall patterns were defined using data from rainfall stations located in the watershed of the reservoir, covering the period 1912 to 1934 . Flows were determined from limnimetric data discharge measurements and the formula of Aguiar (Aguiar 1978). The summary of the technical characteristics is given as Table I and Figure 2.

The installation of the spillway is divided into 12 spans of 13 pillars, each one could be closed by radial floodgates. The threshold of the spillway is at elevation $199.50 \mathrm{~m}$, and it was built wide, providing

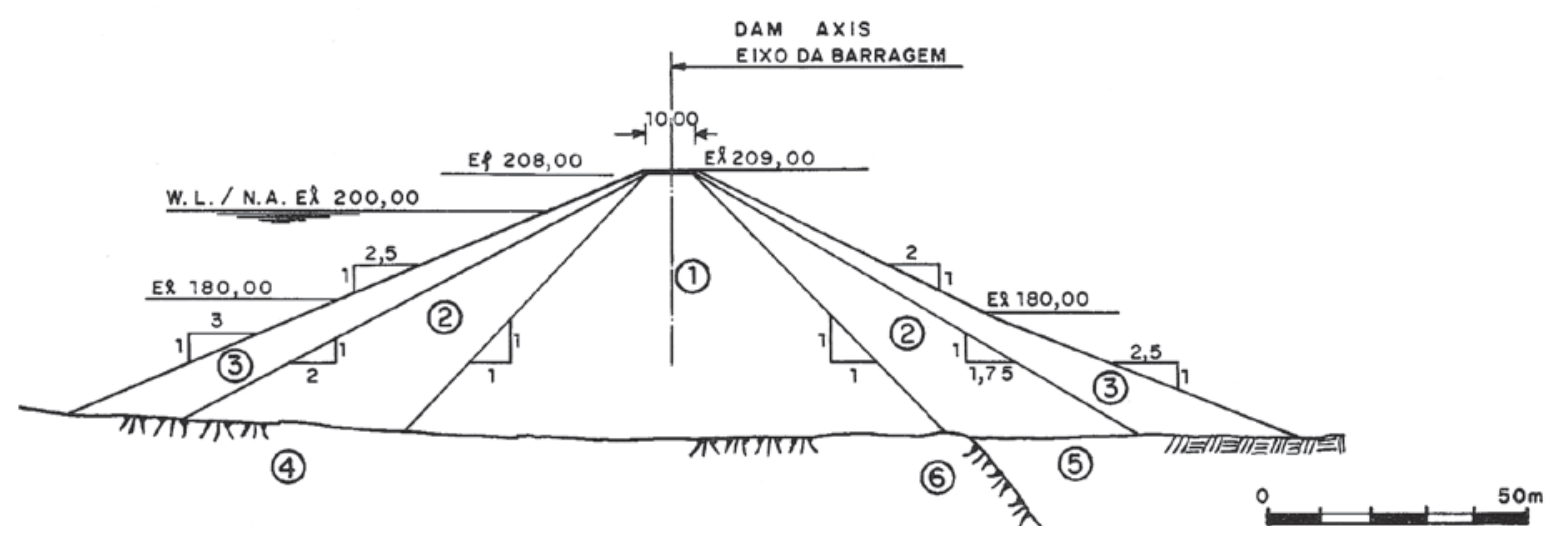

Figure 2 - Dam Orós (Araújo 1990). 
TABLE I

Technical features of dam Orós (Araújo 1990).

\begin{tabular}{|c|c|}
\hline \multicolumn{2}{|c|}{ TECHNICAL FEATURES } \\
\hline Reservoir Capacity & $1,940,000,000 \mathrm{~m}^{3}$ \\
\hline Location $\backslash$ System & Orós - Ceará \Upper Jaguaribe \\
\hline Geographic coordinates (UTM) & $508313 x ; 9310493 y$ \\
\hline River barred & Jaguaribe \\
\hline Watershed $\backslash$ Hydraulic basin & $25,000 \mathrm{Km}^{2} \backslash 35,000$ ha \\
\hline Average annual rainfall & $860 \mathrm{~mm}$ \\
\hline Maximum discharge & $5,200 \mathrm{~m}^{3} / \mathrm{s}$ \\
\hline Minimum $\backslash$ Maximum elevation & $160 \mathrm{~m} \backslash 209 \mathrm{~m}$ \\
\hline Regulated flow & $20.40 \mathrm{~m}^{3} / \mathrm{s}$ \\
\hline Annual average inflow volume & $5,200 \mathrm{~m}^{3} / \mathrm{s}$ \\
\hline Maximum water level & $208 \mathrm{~m}$ \\
\hline \multicolumn{2}{|c|}{ MAIN DAM (type land zoned) } \\
\hline Maximum height & $54 \mathrm{~m}$ \\
\hline Maximum width of the base & $278 \mathrm{~m}$ \\
\hline Extending $\backslash$ width of crown & $670 \mathrm{~m} \backslash 10 \mathrm{~m}$ \\
\hline Radius of curvature & $160 \mathrm{~m}$ \\
\hline \multicolumn{2}{|c|}{ SPILLWAY (type surface free profile Creager) } \\
\hline Length $\backslash$ Free length & $180 \mathrm{~m} \backslash 160 \mathrm{~m}$ \\
\hline Pillars & 13 pillars separate axis at $14 \mathrm{~m}$ \\
\hline Base elevation (Threshold) & $199.50 \mathrm{~m}$ \\
\hline Maximum discharge expected & $5,100 \mathrm{~m}^{3} / \mathrm{s}$ \\
\hline Rematch & $9.56 \mathrm{~m}$ \\
\hline Maximum water depth design & $8.5 \mathrm{~m}$ \\
\hline
\end{tabular}

for the placement of radial floodgates and "stop logs". Thus, it does not have the ideal size, from the standpoint of a hydraulic threshold spillway. For this reason the check was made in the design calculation according to two different methods:

1. Calculation according to the formula of discharge based on a discharge coefficient $\mu=0.55$ for ridges in a broad, flat and round:

$\mathrm{Q}=(2 / 3) \mu \mathrm{b}(2 \mathrm{~g})^{1 / 2} \mathrm{~h}^{3 / 2}$

Where: $\mu=0.55$ (discharge coefficient); $b=160 \mathrm{~m}$ (width of runoff); $\mathrm{h}=8.5 \mathrm{~m}$ (maximum spillway water depth).

Then we have: $\mathrm{Q}=6,439.75 \mathrm{~m}^{3} / \mathrm{s}$.
We made two calculations, with a total width of the ridge $(b=160 \mathrm{~m})$ and a reduced width $(b=$ $146 \mathrm{~m})$. The $\mathrm{b}=146 \mathrm{~m}$ width was adopted for the case where there are radial floodgates and one of them can not be opened for reasons of operational failures at the maximum flow (rule of $n-1)$. For the design of the spillway discharge, $\mathrm{Q}=5,200 \mathrm{~m}^{3} / \mathrm{s}$, we can deduce:

for $\mathrm{b}=146 \mathrm{~m}$, then $\mathrm{h}=7.8 \mathrm{~m}$ (just one gate open); for $b=160 \mathrm{~m}$, then $\mathrm{h}=7.4 \mathrm{~m}$ (all gates open).

2. Calculation for large dam crest (according Rehbock): The hydraulic design made use of the following formulas: 
$\min H=(3 / 2)\left(Q^{2} /\left(b^{2} g\right)\right)^{1 / 3}$

$\mathrm{t}-\mathrm{p}=\min \mathrm{H}+0.3 \mathrm{v}^{2} /(2 \mathrm{~g})-\mathrm{v}^{2} /(2 \mathrm{~g})$

$\mathrm{v}=(2 \mathrm{~g}(\mathrm{t}-\mathrm{p}-\min \mathrm{H}) /(-0.70)) 1 / 2$

Where: $\mathrm{Q}=5,200 \mathrm{~m}^{3} / \mathrm{s} ; \mathrm{b}=160 \mathrm{~m} ; \mathrm{p}=0.5 \mathrm{~m} ; \mathrm{g}=$ $9.81 \mathrm{~m} / \mathrm{s}^{2}$ (acceleration of gravity).

Thus: $\operatorname{minH}=7.4 \mathrm{~m}$ (Waterline discharge); $\mathrm{v}=2.54 \mathrm{~m}^{2} / \mathrm{s}$ (Approximate velocity of flow in front of the pillars).

The line of hydraulic potential along with the amount due to strangulation of pillars, could rise up to $\operatorname{minH}+0.3 \mathrm{v}^{2} / 2 \mathrm{~g}$, resulting in a static level of the reservoir as possible damming of $9.7 \mathrm{~m}$.

The results of rough calculations show very close values, which proves that the design discharge $\mathrm{Q}=5,200 \mathrm{~m}^{3} / \mathrm{s}$ can be discharged through the spillway.

The elevation of water level is $7.4 \mathrm{~m}$ in case of $\mathrm{b}=160 \mathrm{~m}$. With the reduced width for $\mathrm{b}=146 \mathrm{~m}$, the water elevation is $7.8 \mathrm{~m}$. The remaining security gaps to the crown of the dam would be $1.1 \mathrm{~m}$ and $0.7 \mathrm{~m}$, respectively, which ensures that there will not be transhipment on the dam crest.

THRESHOLd AMOUNT OF THE SPILLWAY (DAM CREST)

To check the flow capacity of the second crest (elevation $209 \mathrm{~m}$ ) that, for not having more data about, proceeded to a preliminary examination of the profile constructed.

Thus, for this reason, it was taken as an ideal profile based Creager and Justin, for a load of spillway $9 \mathrm{~m}$. The comparison with the run in the spillway had a relatively good agreement.

To calculate the discharge coefficient for different loads and the spillway discharge was adopted a fillet radius $r=6 \mathrm{~m}$. The calculation was made with the formula of Rehbock:

$\mu=0.312+\left(0.3-0.01\left(5-\mathrm{h} /{ }^{2}\right) 2\right)^{1 / 2}+0.09 \mathrm{~h} / \mathrm{p}$
Where: $\mu$ is the discharge coefficient; $h$ the load chosen spillway; $r$ the fillet radius and $p$ the water depth in front of the spillway.

CAlculation of Releases to DiffERENT LoAdS OF THE SPILLWAY

According to the formulas:

$\mathrm{Q}=(2 / 3) \mu \mathrm{b}(2 \mathrm{~g})^{1 / 2} \mathrm{~h}^{3 / 2}$

$\mu=0.312+\left(0.3-0.01(5-\mathrm{h} / 2)^{2}\right)^{1 / 2}+0.09 \mathrm{~h} / \mathrm{p}$

The load of the spillway $\mathrm{h}=9.0 \mathrm{~m}$ for $\mathrm{Q}=$ $5,200 \mathrm{~m}^{3} / \mathrm{s}$ was obtained from the data discharge. The pool of water directly above the threshold is approximately $7.4 \mathrm{~m}$. The safety gap in relation to the crowning of the side walls will be about 8.5 $\mathrm{m}$, in the case of storage without wave formation. According Creager and Justin (Aguiar 1978), the ideal profile of the hydrological point of view, with a load of spillway $7.4 \mathrm{~m}$. We found a good agreement between the two profiles.

Hydraulic Performance CONSIDERATIONS

We consider a performance-function which is represented by the difference between the maximum depth of the spillway flow (design) and calculated for maximum influent flow:

$\mathrm{P}\left(\mathrm{h}>\mathrm{H}_{\mathrm{adm}}\right)=\mathrm{P}(\mathrm{Z}<0)$

$\mathrm{Z}=\mathrm{H}_{\mathrm{adm}}-\mathrm{h}$

Where: $\mathrm{h}=$ function $(\mathrm{Q}, \mu, \mathrm{b}, \mathrm{R}) ; \mathrm{H}_{\mathrm{adm}}$ the maximum permissible water depth design; $\mathrm{R}$ is the damping coefficient of the reservoir.

$R Q=(2 / 3) \mu b(2 g)^{1 / 2} h^{3 / 2}$

$\mathrm{k}=\left(3 /\left(2(2 \mathrm{~g})^{1 / 2}\right)\right)=0.339$

$\mathrm{h}=\left(3 \mathrm{RQ} /\left(2 \mu \mathrm{b}(2 \mathrm{~g})^{1 / 2}\right)\right)^{2 / 3}=(\mathrm{kRQ} /(\mu \mathrm{b}))^{2 / 3}=$ $(0.339 \mathrm{RQ} /(\mu \mathrm{b}))^{2 / 3}$

$\mathrm{Z}=\mathrm{H}_{\mathrm{adm}}-0.486((\mathrm{RQ}) /(\mu \mathrm{b}))^{2 / 3}$

The full study of the project (Ceará 2000) led us to obtain the basic variables considered random, statistically characterized as Tables II and III. 
TABLE II

Data from studies of floods.

\begin{tabular}{|c|c|c|c|c|}
\hline Variable & Description & Average & CV & DS \\
\hline $\mathrm{b}(\mathrm{m})$ & Width of the spillway & 160.00 & 0.06 & Normal \\
\hline$\mu$ & Discharge coefficient & 0.55 & 0.07 & Normal \\
\hline $\mathrm{R}$ & Damping coefficient & 0.89 & 0.14 & Normal \\
\hline $\mathrm{Q}\left(\mathrm{m}^{3} / \mathrm{s}\right)$ & Flow (Pessimistic view) & $1,000.00$ & 1.51 & Gumbel \\
\hline
\end{tabular}

Where: DS the statistical distribution; $\mathrm{CV}$ is the coefficient of variation (Standard deviation / Average) according with Ang and Tang (1984) that define probability as a probabilistic measure of security of a system; Gumbel distribution according with Villela and Mattos (1975).

TABLE III

Guarantee coefficients (Ceará 2000).

\begin{tabular}{|c|c|}
\hline Guarantee (\%) & Q90 \\
\hline CV & 1.50 \\
\hline Average runoff $\left(\mathrm{m}^{3} / \mathrm{s}\right)$ & 768.42 \\
\hline Annual volume regulated $\left(\mathrm{Hm}^{3}\right)$ & 367.79 \\
\hline Flow regulated $\left(\mathrm{m}^{3} / \mathrm{s}\right)$ & 15.77 \\
\hline Maximum failure $\left(\mathrm{months}^{3}\right)$ & 31 \\
\hline Annual frequence of failure $(\%)$ & 17.95 \\
\hline Average of bloodletting $\left(\mathrm{Hm}^{3} /\right.$ year $)$ & 360.75 \\
\hline Average evaporation $\left(\mathrm{Hm}^{3} /\right.$ year $)$ & 68.31 \\
\hline
\end{tabular}

RISK ANALYSIS CONSIDERATIONS

According to Molak (1997), risk analysis is defined as "a body of knowledge that evaluates and determines the probability of an adverse effect of an agent (chemical, physical or otherwise), industrial process, technology, or natural process." It comprises two steps: the quantification or identification and quantification of risks or risk assessment. The first refers to the knowledge of these uncertainties and the types of risks, because of their form and occurrence, usually by assigning values in cognitive scales. The quantification and risk assessment, involving the calculation processes and resulting analysis of the components in the study environment. This analysis leads to risk management, with the conclusion of the behavioral attitudes of the decision-makers agents, also considering a whole systems analysis, within deterministic and probabilistic approaches.

Several numerical methods are available in the technical literature, however, for this work, we chose some with different complexities, which are considered appropriate for the case studied:

1. Monte Carlo simulation.

It is a very simple method, useful in cases of non-linear functions systems. According to Ang and Tang (1984), it is advisable in cases of impossibility of an appropriate analytical solution. It consists in generate simulations from their probability distributions, sets of values $\mathrm{Xi}$, in order to calculate a set of values of $Z$, considered the performancefunction, ie, $Z=C-B=g\left(X_{i}\right), i=1, \ldots, n$.

Where: $\mathrm{C}$ is the cost; $\mathrm{B}$ the benefit; $\mathrm{g}$ a multivariable function.

The probability of failure is then assessed by the total of negative values of $Z$, and $Z$ number of events generated: $\mathrm{PF}=\mathrm{NZ}_{<0} / \mathrm{NZ}$.

\section{PEM (Point Estimate Method).}

Emerged to simplify, bypassing the difficulties of determining the function-performance derived, by the development of Taylor series, used by class methods FOSM (First-Order Second-Moment). 
Its main characteristic is the analogy between probability distribution and vertical distribution of loads on a rigid system.

\section{AFOSM (Advanced First-Order Second-Moment).}

According to Vieira (2005), AFOSM is a method that consists in the development of performancefunction $Z=g\left(X_{i}\right)$, through its expansion in Taylor series around the point $X_{i}$, on the surface of failure, rather than considering the midpoint $\left(\mu \mathrm{X}_{\mathrm{i}}\right)$.

Where: $\mathrm{g}$ is a multivariable function.

All methods used were implemented computationally with due consideration, aiming at a fast view and analytical of the various scenarios evaluated.

\section{RESULTS}

The results were obtaining from computational processing, according with formulas previously presented and shown in Tables IV to VII.

The main risk formula used is:

$\mathrm{Z}=\operatorname{Hadm}-\mathrm{f}(\mathrm{b}, \mu, \mathrm{R}, \mathrm{Q})<0$

Where: $\mathrm{Z}$ is the performance function; Hadm the allowable water depth $(\mathrm{m})$; $\mathrm{f}$ is a multivariable function; $b$ the free length of the spillway (m); R the damping coefficient; Q the flow (m3/s); SD the statistical distribution; Var is the variance; $\mathrm{Sd}$ the standard deviation; CV the coefficient of variation; $\mathrm{K}$ dimensionless index; Risk is the risk index.

TABLE IV

Case of $b=160 \mathrm{~m}, \mathrm{H}_{\mathrm{adm}}=8.5 \mathrm{~m}$, no locks (Free-flow).

\begin{tabular}{|c|c|c|c|c|c|c|c|}
\hline \multirow{2}{*}{$\begin{array}{l}\text { Monte } \\
\text { Carlo }\end{array}$} & $\mathrm{H}_{\text {minimum }}$ & $\mathrm{H}_{\text {average }}$ & $\mathrm{H}_{\text {maximum }}$ & Iterations (N) & $\mathrm{N}_{\mathrm{n}}(\mathrm{Z}<0)$ & $\mathrm{K}=\mathrm{N} / \mathrm{N}_{\mathrm{n}}$ & Risk (\%) \\
\hline & 4.5489 & 4.5829 & 9.5126 & 500 & 1 & 0.0020 & 0.2000 \\
\hline \multirow{19}{*}{ PEM } & Setup & $\mathrm{b}$ & $\mu$ & $\mathrm{R}$ & Q & $\mathrm{Z}$ & $Z^{2}$ \\
\hline & ++++ & \multirow{8}{*}{169.600} & \multirow{4}{*}{0.589} & \multirow{2}{*}{1.015} & $2,510.000$ & 4.288 & 18.386 \\
\hline & +++- & & & & -510.000 & 7.044 & 49.621 \\
\hline & ++-+ & & & \multirow{2}{*}{0.765} & $2,510.000$ & 5.009 & 25.094 \\
\hline & ++-- & & & & -510.000 & 7.294 & 53.197 \\
\hline & +-++ & & \multirow{4}{*}{0.512} & \multirow{2}{*}{1.015} & $2,510.000$ & 3.875 & 15.017 \\
\hline & +-+- & & & & -510.000 & 6.902 & 47.631 \\
\hline & +--+ & & & \multirow{2}{*}{0.765} & $2,510.000$ & 4.667 & 21.784 \\
\hline & +--- & & & & -510.000 & 7.175 & 51.486 \\
\hline & -+++ & \multirow{8}{*}{150.400} & \multirow{4}{*}{0.589} & \multirow{2}{*}{1.015} & $2,510.000$ & 3.937 & 15.497 \\
\hline & -++- & & & & -510.000 & 6.923 & 47.925 \\
\hline & -+-+ & & & & $2,510.000$ & 4.718 & 22.263 \\
\hline & -+-- & & & & -510.000 & 7.193 & 51.739 \\
\hline & --++ & & & 1015 & $2,510.000$ & 3.489 & 12.176 \\
\hline & --+- & & $0=512$ & & -510.000 & 6.768 & 45.809 \\
\hline & ---+ & & 0.512 & 765 & $2,510.000$ & 4.348 & 18.903 \\
\hline & ---- & & & 0.100 & -510.000 & 7.065 & 49.913 \\
\hline & $\mathrm{Z}_{\mathrm{m}}$ & $\operatorname{Var}(\mathrm{Z})$ & $\mathrm{Sd}(Z)$ & $\mathrm{W}=\mathrm{E}(\mathrm{Z}) / \mathrm{Sd}(\mathrm{Z})$ & Normal (W) & $\mathrm{K}=1-\mathrm{N}_{\mathrm{w}}$ & Risk (\%) \\
\hline & 5.6685 & 2.1557 & 1.4682 & 3.8608 & 0.9999 & 0.0001 & 0.0057 \\
\hline$\triangle \mathrm{FOSM}$ & $\mathrm{Z}_{\mathrm{m}}$ & $\operatorname{Var}(\mathrm{Z})$ & $\mathrm{Sd}(\mathrm{Z})$ & & & $\mathrm{K}$ & Risk (\%) \\
\hline & 6.2271 & 5.2996 & 2.3021 & & & 0.0034 & 0.3415 \\
\hline
\end{tabular}


TABLE V

Case of $b=146 \mathrm{~m}, \mathrm{H}_{\mathrm{adm}}=8.5 \mathrm{~m}$ with one existent floodgate closed.

\begin{tabular}{|c|c|c|c|c|c|c|c|}
\hline \multirow{2}{*}{$\begin{array}{l}\text { Monte } \\
\text { Carlo }\end{array}$} & $\mathrm{H}_{\text {minimum }}$ & $\mathrm{H}_{\text {average }}$ & $\mathrm{H}_{\text {maximum }}$ & Iterations $(\mathrm{N})$ & $\mathrm{N}_{\mathrm{n}}(\mathrm{Z}<0)$ & $\mathrm{K}=\mathrm{N} / \mathrm{N}_{\mathrm{n}}$ & Risk (\%) \\
\hline & 4.5489 & 4.5829 & 9.5126 & 500 & 1 & 0.0020 & 0.2000 \\
\hline \multirow{19}{*}{ PEM } & Setup & $\mathrm{b}$ & $\mu$ & $\mathrm{R}$ & Q & Z & $Z^{2}$ \\
\hline & ++++ & \multirow{8}{*}{154.760} & \multirow{4}{*}{0.589} & \multirow{2}{*}{1.015} & $2,510.000$ & 4.023 & 16.182 \\
\hline & +++- & & & & -510.000 & 6.953 & 48.338 \\
\hline & ++-+ & & & \multirow{2}{*}{0.765} & $2,510.000$ & 4.790 & 22.941 \\
\hline & ++-- & & & & -510.000 & 7.218 & 52.095 \\
\hline & +-++ & & \multirow{4}{*}{0.512} & \multirow{2}{*}{1.015} & $2,510.000$ & 3.584 & 12.845 \\
\hline & +-+- & & & & -510.000 & 6.801 & 46.253 \\
\hline & +--+ & & & \multirow{2}{*}{0.765} & $2,510.000$ & 4.426 & 19.591 \\
\hline & +--- & & & & -510.000 & 7.092 & 50.296 \\
\hline & -+++ & \multirow{8}{*}{137.240} & \multirow{4}{*}{0.589} & \multirow{2}{*}{1.015} & $2,510.000$ & 3.649 & 13.318 \\
\hline & -++- & & & & -510.000 & 6.824 & 46.561 \\
\hline & -+-+ & & & \multirow{2}{*}{0.765} & $2,510.000$ & 4.480 & 20.073 \\
\hline & -+-- & & & & -510.000 & 7.111 & 50.562 \\
\hline & --++ & & \multirow{4}{*}{0.512} & \multirow{2}{*}{1.015} & $2,510.000$ & 3.174 & 10.075 \\
\hline & --+- & & & & -510.000 & 6.659 & 44.346 \\
\hline & ---+ & & & \multirow{2}{*}{0.765} & $2,510.000$ & 4.086 & 16.699 \\
\hline & ---- & & & & -510.000 & 6.975 & 48.645 \\
\hline & $\mathrm{Z}_{\mathrm{m}}$ & $\operatorname{Var}(Z)$ & $\mathrm{Sd}(\mathrm{Z})$ & $\mathrm{W}=\mathrm{E}(\mathrm{Z}) / \mathrm{Sd}(\mathrm{Z})$ & Normal (W) & $\mathrm{K}=1-\mathrm{N}_{\mathrm{w}}$ & Risk (\%) \\
\hline & 5.4902 & 2.4356 & 1.5606 & 3.5179 & 0.9998 & 0.0002 & 0.0217 \\
\hline \multirow{2}{*}{ AFOSM } & $\mathrm{Z}_{\mathrm{m}}$ & $\operatorname{Var}(Z)$ & $\mathrm{Sd}(\mathrm{Z})$ & & & $\mathrm{K}$ & Risk (\%) \\
\hline & 6.0841 & 5.9877 & 2.4470 & & & 0.0065 & 0.6453 \\
\hline
\end{tabular}

TABLE VI

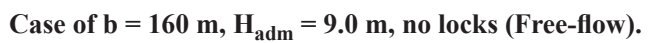

\begin{tabular}{|c|c|c|c|c|c|c|c|}
\hline \multirow{2}{*}{$\begin{array}{l}\text { Monte } \\
\text { Carlo }\end{array}$} & $\mathrm{H}_{\text {minimum }}$ & $\mathrm{H}_{\text {average }}$ & $\mathrm{H}_{\text {maximum }}$ & Iterations $(\mathrm{N})$ & $\mathrm{N}_{\mathrm{n}}(\mathrm{Z}<0)$ & $\mathrm{K}=\mathrm{N} / \mathrm{N}_{\mathrm{n}}$ & Risk (\%) \\
\hline & 4.5489 & 4.5829 & 9.5126 & 500 & 0 & 0.0000 & 0.0000 \\
\hline \multirow{9}{*}{ PEM } & Setup & $\mathrm{b}$ & $\mu$ & $\mathrm{R}$ & Q & $\mathrm{Z}$ & $Z^{2}$ \\
\hline & ++++ & \multirow{8}{*}{169.600} & \multirow{4}{*}{0.589} & \multirow{2}{*}{1.015} & $2,510.000$ & 4.788 & 22.924 \\
\hline & +++- & & & & -510.000 & 7.544 & 56.915 \\
\hline & ++-+ & & & & $2,510.000$ & 5.509 & 30.354 \\
\hline & ++-- & & & 0.100 & -510.000 & 7.794 & 60.740 \\
\hline & +-++ & & \multirow{4}{*}{0.512} & \multirow{2}{*}{1.015} & $2,510.000$ & 4.375 & 19.142 \\
\hline & +-+- & & & & -510.000 & 7.402 & 54.783 \\
\hline & +--+ & & & \multirow{2}{*}{0.765} & $2,510.000$ & 5.167 & 26.702 \\
\hline & +--- & & & & -510.000 & 7.675 & 58.911 \\
\hline
\end{tabular}


TABLE VI (CONTINUATION)

\begin{tabular}{|c|c|c|c|c|c|c|c|}
\hline \multirow{3}{*}{$\begin{array}{l}\text { Monte } \\
\text { Carlo }\end{array}$} & $\mathrm{H}_{\text {minimum }}$ & $\mathrm{H}_{\text {average }}$ & $\mathrm{H}_{\text {maximum }}$ & Iterations $(\mathrm{N})$ & $\mathrm{N}_{\mathrm{n}}(\mathrm{Z}<0)$ & $\mathrm{K}=\mathrm{N} / \mathrm{N}_{\mathrm{n}}$ & Risk (\%) \\
\hline & 4.5489 & 4.5829 & 9.5126 & 500 & 0 & 0.0000 & 0.0000 \\
\hline & Setup & $\mathrm{b}$ & $\mu$ & $\mathrm{R}$ & Q & $\mathrm{Z}$ & $Z^{2}$ \\
\hline \multirow{10}{*}{ PEM } & -+++ & \multirow{8}{*}{150.400} & \multirow{4}{*}{0.589} & \multirow{2}{*}{1.015} & $2,510.000$ & 4.437 & 19.684 \\
\hline & -++- & & & & -510.000 & 7.423 & 55.098 \\
\hline & -+-+ & & & & $2,510.000$ & 5.218 & 27.231 \\
\hline & -+- & & & 0.765 & -510.000 & 7.693 & 59.182 \\
\hline & --++ & & \multirow{4}{*}{0.512} & \multirow{2}{*}{1.015} & $2,510.000$ & 3.989 & 15.916 \\
\hline & --+- & & & & -510.000 & 7.268 & 52.828 \\
\hline & ---+ & & & \multirow{2}{*}{0.765} & $2,510.000$ & 4.848 & 23.501 \\
\hline & ---- & & & & -510.000 & 7.565 & 57.228 \\
\hline & $\mathrm{Z}_{\mathrm{m}}$ & $\operatorname{Var}(\mathrm{Z})$ & $\mathrm{Sd}(\mathrm{Z})$ & $\mathrm{W}=\mathrm{E}(\mathrm{Z}) / \mathrm{Sd}(\mathrm{Z})$ & Normal (W) & $\mathrm{K}=1-\mathrm{N}_{\mathrm{w}}$ & Risk (\%) \\
\hline & 6.1685 & 2.1557 & 1.4682 & 4.2013 & 1.0000 & 0.0000 & 0.0013 \\
\hline \multirow{2}{*}{ AFOSM } & $\mathrm{Z}_{\mathrm{m}}$ & $\operatorname{Var}(\mathrm{Z})$ & $\mathrm{Sd}(\mathrm{Z})$ & & & $\mathrm{K}$ & Risk (\%) \\
\hline & 6.7271 & 5.2996 & 2.3021 & & & 0.0017 & 0.1738 \\
\hline
\end{tabular}

TABLE VII

Case of $b=146 \mathrm{~m}, H_{\mathrm{adm}}=9.0 \mathrm{~m}$ (with one existent floodgate closed).

\begin{tabular}{|c|c|c|c|c|c|c|c|}
\hline \multirow{2}{*}{$\begin{array}{l}\text { Monte } \\
\text { Carlo }\end{array}$} & $\mathrm{H}_{\text {minimum }}$ & $\mathrm{H}_{\text {average }}$ & $\mathrm{H}_{\text {maximum }}$ & Iterations $(\mathrm{N})$ & $\mathrm{N}_{\mathrm{n}}(\mathrm{Z}<0)$ & $\mathrm{K}=\mathrm{N} / \mathrm{N}_{\mathrm{n}}$ & Risk (\%) \\
\hline & 4.5489 & 4.5829 & 9.5126 & 500 & 0 & 0.0000 & 0.0000 \\
\hline \multirow{19}{*}{ PEM } & Setup & $\mathrm{b}$ & $\mu$ & $\mathrm{R}$ & Q & $\mathrm{Z}$ & $Z^{2}$ \\
\hline & ++++ & \multirow{8}{*}{154.760} & \multirow{4}{*}{0.589} & \multirow{2}{*}{1.015} & $2,510.000$ & 4.526 & 20.455 \\
\hline & +++- & & & & -510.000 & 7.453 & 55.541 \\
\hline & ++-+ & & & \multirow{2}{*}{0.765} & $2,510.000$ & 5.290 & 27.981 \\
\hline & ++-- & & & & -510.000 & 7.718 & 59.562 \\
\hline & +-++ & & \multirow{4}{*}{0.512} & \multirow{2}{*}{1.015} & $2,510.000$ & 4.084 & 16.679 \\
\hline & +-+- & & & & -510.000 & 7.301 & 53.304 \\
\hline & +--+ & & & \multirow{2}{*}{0.765} & $2,510.000$ & 4.926 & 24.267 \\
\hline & +--- & & & & -510.000 & 7.592 & 57.638 \\
\hline & -+++ & \multirow{8}{*}{137.240} & \multirow{4}{*}{0.589} & \multirow{2}{*}{1.015} & $2,510.000$ & 4.149 & 17.217 \\
\hline & -++- & & & & -510.000 & 7.324 & 53.634 \\
\hline & -+-+ & & & 0765 & $2,510.000$ & 4.980 & 24.803 \\
\hline & -+-- & & & 0.100 & -510.000 & 7.611 & 57.923 \\
\hline & --++ & & & 1015 & $2,510.000$ & 3.674 & 13.499 \\
\hline & --+- & & 0512 & 1.010 & -510.000 & 7.159 & 51.255 \\
\hline & ---+ & & & 0765 & $2,510.000$ & 4.586 & 21.035 \\
\hline & ---- & & & 0.100 & -510.000 & 7.475 & 55.869 \\
\hline & $\mathrm{Z}_{\mathrm{m}}$ & $\operatorname{Var}(\mathrm{Z})$ & $\mathrm{Sd}(\mathrm{Z})$ & $\mathrm{W}=\mathrm{E}(\mathrm{Z}) / \mathrm{Sd}(\mathrm{Z})$ & Normal (W) & $\mathrm{K}=1-\mathrm{N}_{\mathrm{w}}$ & Risk (\%) \\
\hline & 5.9902 & 2.4356 & 1.5606 & 3.8383 & 0.9999 & 0.0001 & 0.0062 \\
\hline$\triangle \mathrm{EOSM}$ & $\mathrm{Z}_{\mathrm{m}}$ & $\operatorname{Var}(\mathrm{Z})$ & $\mathrm{Sd}(\mathrm{Z})$ & & & $\mathrm{K}$ & Risk (\%) \\
\hline ATI USIVI & 6.5841 & 5.9877 & 2.4470 & & & 0.0036 & 0.3565 \\
\hline
\end{tabular}




\section{DISCUSSION}

While reading the bibliografic material, the subject "risk" is approached several times, but always in reference to traditional empirical formula and no further details. The formatting of the project did not consider the techniques of risk analysis, by the time they were prepared: designers depended basically on their experience and sensitivity.
After computations more accurate and more appropriate models and methods, we found that increased security considerations were used, and it was proven by the calculations made in the various scenarios evaluated, a percentage of low risk in relation to overcoming the water depth spillway in the original. The Table VIII summarizes all the calculations:

TABLE VIII

Resume of risk analysis indicators.

\begin{tabular}{|c|c|c|c|c|}
\hline Method & $\mathbf{b}=\mathbf{1 6 0} ; \mathbf{H}_{\mathbf{a d m}}=\mathbf{8 . 5}$ & $\mathbf{b}=\mathbf{1 4 6} ; \mathbf{H}_{\mathbf{a d m}}=\mathbf{8 . 5}$ & $\mathbf{b}=\mathbf{1 6 0} ; \mathbf{H}_{\mathbf{a d m}}=\mathbf{9 . 0}$ & $\mathbf{b}=\mathbf{1 4 6} ; \mathbf{H}_{\mathbf{a d m}}=\mathbf{9 . 0}$ \\
\hline AFOSM & $0.3415 \%$ & $0.6453 \%$ & $0.1738 \%$ & $0.3565 \%$ \\
\hline PEM & $0.0057 \%$ & $0.0217 \%$ & $0.0013 \%$ & $0.0062 \%$ \\
\hline Monte Carlo & $0.2000 \%$ & $0.2000 \%$ & $0.0000 \%$ & $0.0000 \%$ \\
\hline
\end{tabular}

Where: PEM is the "Point Estimate Method"; AFOSM is the "Advanced First-Order SecondMoment" method; $b$ the free length of the spillway (m); Hadm the allowable water depth (m).

In the same Table VIII, we see that the risks to overcome the water depth of the project are almost insignificant to the current reality. With the considerations in setting the existence of floodgates in various settings (opened and closed), as well as a higher influent flow, is expected to be a significant increase in indicators of risk.

For this work expansion, within a strategic vision, we suggest a study to assess the need for placement of floodgates in the dam, since it would improve the ability of the reservoir to 4 (four) billion cubic meters, nearly doubling the maximum amount accumulated, naturally necessary to human needs in the near future, within the context of global climate changes.

\section{RESUMO}

Este trabalho apresenta a aplicação prática de conceitos, e alguns métodos de análise de risco, para verificar a possibilidade de superação da lâmina d'água de projeto no vertedouro da barragem Orós, pelo excesso de vazão afluente. Também foram avaliadas as fórmulas empíricas do projeto original. Devido à dificuldade de obtenção de dados do projeto da barragem, visto que o final da cons- trução data de 11 de janeiro de 1961, minimizamos os efeitos de algumas variáveis nos cálculos, levando à simplificação do cenário em estudo. Para uma melhor avaliação e caracterização, algumas variáveis do modelo, como nível d'água, acumulação e vazão do vertedouro, tiveram dados atualizados até 28 de junho de 2011. Demonstramos então a importância da análise de risco para o projeto, construção e operação de barragens em grandes reservatórios.

Palavras-chave: Análise de risco, barragens públicas, reservatórios, gestão de recursos hídricos.

\section{REFERENCES}

AGUIAR FG. 1978. Estudo hidrométrico do Nordeste brasileiro (Excertos). B. Técnico. Fortaleza: DNOCS 36(2): 129-204.

ANG AHS AND TANG WH. 1984. Probability Concepts in Engineering Planning and Design. Vol. 2. New York: J Wiley \& Sons Inc., $562 \mathrm{p}$.

ARAÚJO JA. 1990. Barragens no Nordeste do Brasil: Experiência do DNOCS em barragens na região semi-árida. $2^{\mathrm{a}}$ ed., Fortaleza: DNOCS, 328 p.

CEARÁ. 2000. Companhia de Gestão de Recursos Hídricos (COGERH). Plano de Gerenciamento das Águas da Bacia do Rio Jaguaribe. In: Estudos Complementares e de Base de Hidrologia. Fortaleza: COGERH, 197 p.

MOLAK VE. 1997. Fundamentals of Risk Analysis and Risk Management. New York: CRC Press, USA, 423 p.

VIEIRA VPB. 2005. Análise de Riscos em Recursos Hídricos Fundamentos e Aplicações. Porto Alegre: ABRH Coleção ABRH 10: 361.

Villela SM ANd Mattos A. 1975. Hidrologia Aplicada. São Paulo: McGraw-Hill do Brasil, 245 p. 